\title{
Cultivars and Phosphorus Fertilization Effects on Growth Parameters of Direct-Seeded Rice
}

\author{
Ajay Pal*, Seema Sepat, R.S. Bana and Arjun Singh \\ Indian Agricultural Research Institute, New Delhi-110012, India \\ *Corresponding author
}

\section{A B S T R A C T}

\begin{tabular}{|l|}
\hline K e y w o r d s \\
$\begin{array}{l}\text { Cultivars, Direct-seeded } \\
\text { Rice, Microbial } \\
\text { inoculants, Phosphorus } \\
\text { fertilization }\end{array}$ \\
\hline Article Info \\
\hline $\begin{array}{l}\text { Accepted: } \\
\text { 26 April } 2018 \\
\text { Available Online: } \\
\text { 10 May } 2018\end{array}$ \\
\hline
\end{tabular}

A field experiment was conducted to study the effect of cultivars and phosphorus (P) applications on growth parameters of direct-seeded rice (DSR) during kharif 2016 at the research farm of ICAR- Central Rainfed Upland Rice Research Station, Hazaribag, Jharkhand. The experiment was laid out in split plot design with three replications. The rice cultivars 'Vandana' 'Anjali' and 'CR Dhan 40' were included in main plots, and seven different $\mathrm{P}$ rates through $\mathrm{SSP}$ and microbial inoculants viz., $0 \mathrm{~kg} \mathrm{ha}^{-1}$, PSB+AM, 30 $\mathrm{kgP}_{2} \mathrm{O}_{5}, 30 \mathrm{~kg} \mathrm{P}_{2} \mathrm{O}_{5}+\mathrm{PSB}+\mathrm{AM}, 60 \mathrm{~kg} \mathrm{P}_{2} \mathrm{O}_{5}, 60 \mathrm{~kg} \mathrm{P}_{2} \mathrm{O}_{5}+\mathrm{PSB}+\mathrm{AM}$ and $90 \mathrm{~kg} \mathrm{P}_{2} \mathrm{O}_{5} \mathrm{ha}^{-1}$ were applied in subplot. Results obtained from the experiment showed that all the growth parameters like plant height, plant tillers $\mathrm{m}^{-2}$, dry matter accumulation $\left(\mathrm{g} \mathrm{m}^{-2}\right)$ and crop growth rate $\left(\mathrm{g} \mathrm{m}^{-2} \mathrm{day}^{-1}\right)$ were recorded higher in rice cultivar ' $\mathrm{CR}$ Dhan 40 ' compared to 'Anjali' and 'Vandana'. Likewise, highest values for all growth parameters were observed with $\mathrm{P}$ application of $90 \mathrm{~kg} \mathrm{P}_{2} \mathrm{O}_{5}$ through SSP which remained at par with $60 \mathrm{~kg} \mathrm{P}_{2} \mathrm{O}_{5}$ supplied through SSP along with microbial inoculants.

\section{Introduction}

Rice is grown under various types of ecologies in India. The transplanting of rice seedlings in puddled soil (PTR) followed by flooding is the most common practice of rice cultivation. This practice consumes lot of water, labour and energy (Kumawat et al., 2016). Moreover, deleterious effect of puddling on soil physical properties is also seen on the subsequent wheat crop grown in rotation. The dry directseeded rice (DSR) is a resource conservation technology which requires less labour, water and often matures earlier than transplanted crops (Mahajan et al., 2017). The higher weed and nematode infestation and iron deficiency are the major problems for achieving higher grain yield of DSR (Kumar et al., 2017).

The Availability of phosphorus is a major concern under direct seeded upland fields in clay loam soils where it is deficient and is a major factor contributing to low yield of rice. The Phosphorus deficiency is more common in dry seeded rice because of more fixation and decreased mobility in the soil. The poor phosphorus acquisition is a major constraint, and therefore use efficiency of $\mathrm{P}$ is very low (15-20 \%). However, $\mathrm{P}$ efficiency can be improved by enhancing internal utilisation efficiency with the use of microbial inoculants (Richardson et al., 2011a). Maiti et al., (2011) 
conducted an experiment to improve $\mathrm{P}$ nutrition of upland rice by application of AM fungi and found that phosphorus uptake and rice yield was significantly increased. Application of PSB has been reported to stimulate nitrogen fixation, production of plant growth promoting substances such as siderophores and lytic enzyme (Stephen et al., 2011). Therefore, a study was conducted to understand the effect of cultivar and $\mathrm{P}$ rates on growth and quality parameters of DSR.

\section{Materials and Methods}

A field experiment was conducted during the kharif season of 2016 at research farm of ICAR- Central Rainfed Upland Rice Research Station, Hazaribag, Jharkhand (235' $\mathrm{N}$, $85^{\circ} 21^{\prime} \mathrm{E}$, and $614 \mathrm{~m}$ above the mean sea level). The soil was clay loam in texture with medium in organic $\mathrm{C}(0.62 \%)$, low in available $\mathrm{N}$ (153 kg ha ${ }^{-1}$ ), available P (10.30 $\mathrm{kg} \mathrm{ha}^{-1}$ ) and high in available $\mathrm{K}\left(380 \mathrm{~kg} \mathrm{ha}^{-1}\right)$ with $\mathrm{pH}$ of 6.8 . The annual rainfall of the experimental site was $1450 \mathrm{~mm}$.

The experiment was laid out in split plot design having three cultivars in the main plots as Vandana, Anjali and CR Dhan 40 and seven different $\mathrm{P}$ fertilization practices in sub plots viz., P1: No P; P2: PSB+AM; P3: $30 \mathrm{~kg}$ $\mathrm{P}_{2} \mathrm{O}_{5}$ ha- ${ }^{1}$ through SSP; P4: $30 \mathrm{~kg} \mathrm{P}_{2} \mathrm{O}_{5} \mathrm{ha}^{-1}$ through SSP+PSB+AM; P5: $60 \mathrm{~kg} \mathrm{P}_{2} \mathrm{O}_{5} \mathrm{ha}^{-1}$ through SSP; P6: $60 \mathrm{~kg} \mathrm{P}_{2} \mathrm{O}_{5}$ ha $^{-1}$ through $\mathrm{SSP}+\mathrm{PSB}+\mathrm{AM}$ and P7: $90 \mathrm{~kg} \mathrm{P}_{2} \mathrm{O}_{5}$ ha- ${ }^{1}$ through SSP. The rice was directly sown with the help of multi-row crop planter using a seed rate of $30 \mathrm{~kg} \mathrm{ha}^{-1}$ at row to row spacing of 20 $\mathrm{cm}$. The recommended dose of $\mathrm{N}$ and $\mathrm{K}$ as 60 $\mathrm{kg} \mathrm{N} \mathrm{ha}{ }^{-1}$ and $40 \mathrm{~kg} \mathrm{~K}_{2} \mathrm{O} \mathrm{ha}^{-1}$, respectively were applied. The half dose of $\mathrm{N}$ and full dose of $\mathrm{K}$ was applied as basal through urea and Muriate of potash, respectively. The various doses of $\mathrm{P}$ were applied as basal through the different combinations of single super phosphate, phosphorus solubilising bacteria
(PSB) and arbuscular mycorrhizae (AM). PSB was inoculated on seeds whereas AM was applied in soil before sowing. The plant height was measured from the base of the plant at ground surface up to the tip of the growing tip of the plant. The five plants were selected randomly from each plot, tagged permanently and plant height was measured at 30 days interval. The number of tillers were counted from one square meter area starting from 30, 60 and 90 DAS and ultimately averaged into tillers $\mathrm{m}^{-2}$. For dry matter accumulation, rice plants from one square meter were cut close to the ground level in each plot at 30,60 and 90 DAS. The samples were then sun-dried for 2-3 days followed by oven drying at $60-65 \pm 2{ }^{\circ} \mathrm{C}$ for 24 hours. Thereafter weighing was done.

\section{Results and Discussion}

All the growth parameters were significantly influenced by different rice cultivars as well as $P$ fertilization practices. The rice cultivar 'Vandana' recorded highest plant height compared to 'Anjali' and 'CR Dhan 40' at 60 DAS and 90 DAS due to genetically tall nature of 'Vandana' cultivar. Inverse linear relationship between plant height and grain yield had been reported by Anwar et al., (2010). The plant height was influenced significantly by the various $\mathrm{P}$ fertilization practices. Among various $\mathrm{P}$ levels, application of $90 \mathrm{~kg} \quad \mathrm{P}_{2} \mathrm{O}_{5}$ through $\mathrm{SSP}$ recorded significantly highest plant height which remained at par with $60 \mathrm{~kg} \mathrm{P}_{2} \mathrm{O}_{5}$ through SSP along with PSB and AM. However, no P fertilization had lowest plant height (Table 4.1). Moreover, application of only microbial inoculants was not effective compared to no $\mathrm{P}$ application but it was found more efficient when applied along with $\mathrm{P}$ through water soluble fertilizers. The application of $\mathrm{P}$ enhanced the water absorption and nutrient uptake from the soil (Kato et al., 2006). This might be one of the reasons behind higher growth of rice plants due to $\mathrm{P}$ fertilization. 
Table.1 Effect of cultivars and phosphorus fertilization on plant height $(\mathrm{cm})$ and plant tillers $\left(\mathrm{m}^{-2}\right)$ of DSR at various growth stages

\begin{tabular}{|c|c|c|c|c|c|}
\hline \multirow[t]{2}{*}{ Treatment } & \multicolumn{3}{|c|}{ Plant height (cm) } & \multicolumn{2}{|c|}{ Plant tillers $\mathbf{m}^{-2}$} \\
\hline & 30 DAS & 60 DAS & 90 DAS & 30 DAS & 60 DAS \\
\hline \multicolumn{6}{|l|}{ Cultivars (C) } \\
\hline Vandana & 40.09 & 70.47 & 102.65 & 143 & 299 \\
\hline Anjali & 39.38 & 66.62 & 97.45 & 144 & 326 \\
\hline CR Dhan 40 & 39.58 & 68.93 & 97.24 & 146 & 367 \\
\hline SEm \pm & 1.17 & 0.99 & 1.42 & 1.08 & 2.92 \\
\hline $\mathrm{CD}(\mathrm{P}=0.05)$ & NS & 3.00 & 4.30 & NS & 8.85 \\
\hline \multicolumn{6}{|c|}{ Phosphorus levels (P) } \\
\hline $\mathbf{P 1}$ & 38.51 & 65.70 & 95.32 & 142 & 317 \\
\hline $\mathbf{P 2}$ & 38.68 & 66.23 & 95.79 & 143 & 319 \\
\hline P3 & 39.37 & 67.82 & 98.32 & 144 & 326 \\
\hline P4 & 39.65 & 68.26 & 98.91 & 145 & 328 \\
\hline P5 & 40.11 & 70.24 & 101.18 & 146 & 338 \\
\hline P6 & 40.60 & 70.84 & 101.85 & 147 & 342 \\
\hline P7 & 40.87 & 71.64 & 102.41 & 148 & 344 \\
\hline SEm \pm & 0.59 & 0.68 & 0.90 & 2.08 & 1.98 \\
\hline $\mathrm{CD}(\mathrm{P}=0.05)$ & NS & 2.06 & 2.73 & NS & 6.00 \\
\hline
\end{tabular}

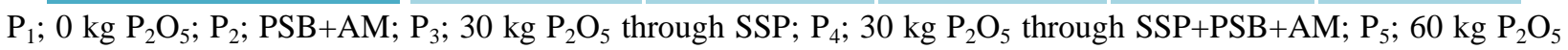
through SSP; $\mathrm{P}_{6} ; 60 \mathrm{~kg} \mathrm{P}_{2} \mathrm{O}_{5}$ through SSP+PSB+AM; $\mathrm{P}_{7} ; 90 \mathrm{~kg} \mathrm{P}_{2} \mathrm{O}_{5}$ through SSP

Table.2 Effect of cultivars and phosphorus fertilization on dry matter accumulation $\left(\mathrm{g} \mathrm{m}^{-2}\right.$ day $\left.^{-1}\right)$ and CGR $\left(\mathrm{g} \mathrm{m}^{-2} \mathrm{day}^{-1}\right)$ of DSR at various growth stages

\begin{tabular}{|c|c|c|c|c|c|c|}
\hline \multirow[t]{2}{*}{ Treatment } & \multicolumn{3}{|c|}{ Dry matter accumulation $\left(\mathrm{g} \mathrm{m}^{-2}\right)$} & \multicolumn{3}{|c|}{ Mean CGR $\left(\mathrm{g} \mathrm{m}^{-2}\right.$ day $\left.^{-1}\right)$} \\
\hline & 30 DAS & 60 DAS & 90 DAS & 30 DAS & 60DAS & 90DAS \\
\hline \multicolumn{7}{|l|}{ Cultivars (C) } \\
\hline Vandana & 68 & 320 & 1013 & 2.29 & 8.39 & 23.10 \\
\hline Anjali & 68 & 329 & 1073 & 2.28 & 8.71 & 24.77 \\
\hline CR Dhan 40 & 69 & 364 & 1155 & 2.31 & 8.94 & 26.35 \\
\hline SEm \pm & 0.43 & 4.41 & 6.72 & 0.04 & 0.08 & 0.18 \\
\hline $\mathrm{CD}(\mathrm{P}=0.05)$ & NS & 13.36 & 20.36 & NS & 0.22 & 0.57 \\
\hline \multicolumn{7}{|c|}{ Phosphorus levels (P) } \\
\hline $\mathbf{P 1}$ & 66 & 321 & 1046 & 2.22 & 8.47 & 24.16 \\
\hline $\mathbf{P 2}$ & 67 & 323 & 1053 & 2.24 & 8.54 & 24.32 \\
\hline P3 & 68 & 333 & 1073 & 2.27 & 8.84 & 24.67 \\
\hline$\overline{P 4}$ & 68 & 336 & 1080 & 2.29 & 8.91 & 24.79 \\
\hline $\mathbf{P 5}$ & 69 & 349 & 1096 & 2.31 & 9.33 & 24.88 \\
\hline P6 & 70 & 351 & 1106 & 2.34 & 9.36 & 25.16 \\
\hline $\mathbf{P 7}$ & 70 & 353 & 1109 & 2.36 & 9.40 & 25.21 \\
\hline SEm \pm & 1.03 & 3.17 & 3.77 & 0.01 & 0.04 & 0.15 \\
\hline $\mathrm{CD}(\mathrm{P}=0.05)$ & NS & 9.60 & 11.42 & NS & 0.12 & 0.43 \\
\hline
\end{tabular}

$\mathrm{P}_{1} ; 0$ kg $\mathrm{P}_{2} \mathrm{O}_{5} ; \mathrm{P}_{2} ; \mathrm{PSB}+\mathrm{AM} ; \mathrm{P}_{3} ; 30 \mathrm{~kg} \mathrm{P}_{2} \mathrm{O}_{5}$ through SSP; $\mathrm{P}_{4} ; 30 \mathrm{~kg} \mathrm{P}_{2} \mathrm{O}_{5}$ through $\mathrm{SSP}+\mathrm{PSB}+\mathrm{AM} ; \mathrm{P}_{5} ; 60 \mathrm{~kg} \mathrm{P}_{2} \mathrm{O}_{5}$ through SSP; $\mathrm{P}_{6} ; 60 \mathrm{~kg} \mathrm{P}_{2} \mathrm{O}_{5}$ through SSP+PSB+AM; $\mathrm{P}_{7} ; 90 \mathrm{~kg} \mathrm{P}_{2} \mathrm{O}_{5}$ through SSP. 
Similarly, numbers of plant tillers $\mathrm{m}^{-2}$ were also influenced significantly by different rice cultivars as well as $\mathrm{P}$ fertilization practices. The rice cultivar ' $\mathrm{CR}$ Dhan 40' registered significantly higher number of tillers $\mathrm{m}^{-2}$ followed by 'Vandana' and 'Anjali' at 60 and 90 DAS. This might de due to faster vigorous growth and genetic characteristic of the variety. The application of $90 \mathrm{~kg} \quad \mathrm{P}_{2} \mathrm{O}_{5}$ through SSP recorded significantly higher number of plant tillers $\mathrm{m}^{-2}$ at 60 and 90 DAS which remained at par with $60 \mathrm{~kg} \mathrm{P}_{2} \mathrm{O}_{5}$ through SSP+ PSB+AM (Table 4.1).

Dry matter accumulation was significantly influenced by the different cultivars and $\mathrm{P}$ fertilization practices. The rice cultivar ' $\mathrm{CR}$ Dhan 40' recorded significantly highest dry matter accumulation followed by 'Vandana' and 'Anjali' at $60\left(364 \mathrm{~g} \mathrm{~m}^{-2}\right)$ and 90 DAS $\left(1155 \mathrm{~g} \mathrm{~m}^{-2}\right)$. This was mainly due to higher synthesis and translocation of photosynthates which resulted in higher dry matter accumulation (Mahajan et al., 2017). In general, the dry matter accumulation was increased with increasing $\mathrm{P}$ rate along with microbial inoculants. Among various $\mathrm{P}$ levels, application of $90 \mathrm{~kg} \mathrm{P}_{2} \mathrm{O}_{5}$ through SSP recorded significantly highest dry matter accumulation at $60\left(353 \mathrm{~g} \mathrm{~m}^{-2}\right)$ and 90 DAS $\left(1109 \mathrm{~g} \mathrm{~m}^{-2}\right)$, which remained at par $(1106 \mathrm{~g}$ $\mathrm{m}^{-2}$ ) with $60 \quad \mathrm{~kg} \quad \mathrm{P}_{2} \mathrm{O}_{5}$ through $\mathrm{SSP}+$ $\mathrm{PSB}+\mathrm{AM}$.

Likewise, The CGR of rice plants was significantly influenced by the different cultivars of rice and $\mathrm{P}$ fertilization (Table 2). The highest CGR was observed in a rice variety 'CR Dhan 40' as compared to other varieties at $31-60$ DAS $\left(8.94 \mathrm{~g} \mathrm{~m}^{-2} \mathrm{day}^{-1}\right)$ and 61 - 90 DAS (26.35 $\mathrm{g} \mathrm{m}^{-2}$ day $^{-1}$ ). However, there was statistically no considerable difference among different varieties of rice at 0-30 DAS. The $\mathrm{P}$ fertilization with $90 \mathrm{~kg} \mathrm{P}_{2} \mathrm{O}_{5}$ through SSP recorded significantly higher crop growth rate over no $\mathrm{P}$ fertilization at 31 -
60 DAS and 61-90 DAS which remained at par with $60 \mathrm{~kg}$ P2O5 through SSP along with PSB and AM.

\section{References}

Anwar, M.P., Juraimi, A.S., Man, A., Puteh, A., Selamat, A. and Begum, M. 2010. Weed suppressive ability of rice (Oryza sativa L.) germplasm under aerobic soil conditions. Australian Journal of Crop Science 4(9): 706-717.

Kato, Y., Abe, J., Kamoshita, A. and Yamagishi, J. 2006. Genotypic variation in root growth angle in rice (Oryza sativa L.) and its association with deep root development in upland fields with different water regimes. Plant and Soil 287:117-129.

Kumar, R., Kumawat, N., Kumar, M. and Kumar, A. 2017. Direct seeded rice: research strategies and opportunities for water and weed management. Oryza 53(4): 354-365.

Kumawat, A., Sepat, S., Kumar, D., Kaur, R. and Jinger, D. 2017. Effect of irrigation scheduling and nitrogen application on productivity and profitability of direct seeded rice (Oryza sativa). Indian Journal of Agronomy 61(4): 506-508.

Mahajan, G., Kaur, G. and Chauhan, B.S. 2017. Seeding rate and genotype effects on weeds and yield of dry-seeded rice. Crop Protection 96: 68-76.

Maiti, D., Singh, C.V., Variar, M., Mandal, N.P. and Anantha, M.S. 2013.Impact of rainfall pattern on native arbuscularmycorrhizal activity influencing phosphorus utilization by direct seeded rainfed upland rice (Oryza sativa L.).Proceedings of the National Academy of Sciences, India Section B: Biological Sciences 83(2): 159-62.

Stephen, J., Shabanamol, S., Rishad, K.S. and Jisha, M.S. 2015. Growth enhancement of rice (Oryza sativa) by phosphate 
solubilising Gluconacetobacter sp. (MTCC 8368) and Burkholderia sp.

(MTCC 8369) under greenhouse conditions. Biotechnology 5:831-837.

\section{How to cite this article:}

Ajay Pal, Seema Sepat, R.S. Bana and Arjun Singh. 2018. Cultivars and Phosphorus Fertilization Effects on Growth Parameters of Direct-Seeded Rice. Int.J.Curr.Microbiol.App.Sci. 7(05): 3612-3616. doi: https://doi.org/10.20546/ijcmas.2018.705.417 